\title{
Degenerative bone changes in TMJ assessed by cone beam computed tomography
}

\author{
Alterações ósseas degenerativas na ATM avaliadas por tomografia computadorizada de feixe cônico
}

\author{
Marcella Quirino de ALMEIDA AZEVEDO' \\ Renata Quirino de ALMEIDA BARROS² \\ Lúcio Flávio Azevedo DONATO3 \\ Michel Nicolau YOUSSEF ${ }^{3}$ \\ Luis Roberto Coutinho MANHÃES JÚNIOR ${ }^{4}$ \\ Francine KühI PANZARELLA ${ }^{4}$
}

\section{ABSTRACT}

\section{Objective}

To assess the degenerative bone changes of the jaw head and the condylar mobility regarding gender and age.

\section{Methods}

The sample was composed of 106 CBCT images for TMJ region from patients over 18 years old, from both genders, from the archives of a radiological clinic in the city of Campina Grande, Paraiba, Brazil. The images were obtained from patients in maximum intercuspal and maximum mouth opening. The images were examined by a radiologist, through the software Xoran CAT ${ }^{\circledR}$, using a monitor with high resolution of and maximum color quality (12 bits) in a low light environment. It was assessed tomographic aspects of bone degenerative changes (flattening, erosion, osteophytes, bone sclerosis and pseudocyst) of both TMJ of each patient. The association among the degenerative changes of the jaw head, gender and age were investigated through Fisher's exact test, G-test and chi-squared test. The data obtained regarding condylar mobility (normo, hyper and hypoexcursion), location (right unilateral, left unilateral and bilateral) were also submitted to descriptive analysis in terms of absolute and relative frequency.

\section{Results}

The most frequent bone alteration was flattening (58.5\%), followed by osteophytes (44.3\%), erosion (22.6\%), sclerosis (13.2\%) and pseudocyst (10.4\%). Regarding condylar mobility it was observed that normoexcursion (71.7\%) was more prevalent.

\section{Conclusion}

The degenerative bone changes occurred more frequently among women and in bilateral location and there was an increasing of alterations according the age. It was not found correlation among condylar mobility and the presence of degenerative bone alterations of the TMJ.

Indexing terms: Temporomandibular joint. Cone-Beam Computed Tomography. Osteoarthritis.

\section{RESUMO}

\section{Objetivo}

Avaliar as alterações ósseas degenerativas na cabeça da mandíbula e a mobilidade condilar com relação ao gênero e à faixa etária.

\section{Métodos}

A amostra foi constituída por 106 exames de TCFC para a região de ATM de pacientes com mais de 18 anos, do arquivo de uma clínica de radiologia odontológica, localizada na cidade de Campina Grande, PB, Brasil. As imagens foram obtidas com os pacientes em máxima intercuspidação e abertura de boca. As imagens foram examinadas por um radiologista, por meio do próprio software do tomógrafo Xoran CAT ${ }^{\circledR}$, usando-se um monitor com alta resolução e máxima qualidade de cor (12 bits) em ambiente com luz reduzida. Foram avaliados os aspectos tomográficos das alterações ósseas degenerativas (facetamento, erosão, osteófitos, esclerose óssea e pseudocisto) de ambas as ATM. As associações entre as alterações degenerativas e o sexo e a faixa etária foram investigadas por meio dos testes exato de Fisher, $\mathrm{G}$ e Qui-quadrado. Os dados obtidos quanto à excursão condilar (normoexcursão, hipoexcursão e hiperexcursão), segundo a localização também foram submetidos a análises descritivas.

\section{Resultados}

As alterações mais frequentes foram o facetamento (58,5\%), seguido de osteófito (44,3\%), erosão (22,6\%), esclerose (13,2\%) e pseudocisto $(10,4 \%)$. Em relação à excursão condilar, observou-se que a normoexcursão foi a mais prevalente $(71,7 \%)$.

\section{Conclusão}

As alterações ósseas degenerativas ocorreram de forma mais frequente em mulheres e de forma bilateral, e houve um aumento da frequência com a idade. Não foi encontrada correlação entre a excursão condilar e a presença de alterações na ATM, sendo a normoexcursão mais frequente.

Termos de indexação: Articulação temporomandibular. Tomografia computadorizada. Osteoartrite.

\footnotetext{
${ }^{1}$ Faculdade Maurício de Nassau, Departamento de Odontologia. Br 232 com a Br 104, KM 68, 1215, Caruaru, PE, Brasil. Correspondência para / Correspondence to: MQA AZEVEDO. E-mail: <marcella_q_almeida@hotmail.com>.

${ }^{2}$ Centro Universitário de João Pessoa, Departamento de Odontologia. João Pessoa, PB, Brasil.

${ }^{3}$ Universidade Cruzeiro do Sul, Departamento de Odontologia. São Paulo, SP, Brasil.

${ }^{4}$ Faculdade São Leopoldo Mandic, Curso de Odontologia, Programa de Pós-Graduação em Odontologia. Campinas, SP, Brasil.
} 


\section{INTRODUCTION}

An etiologic complex of factors such as trauma, emotional stress, muscular hyperactivity, and inflammatory and degenerative diseases may compromise the equilibrium of the temporomandibular joint (TMJ), leading to the development of temporomandibular disorder (TMD)' 1 .

The symptoms of TMD include decreased jaw mobility, pain in masticatory muscles, TMJ pain, joint sounds, and restriction or deviation in mouth opening ${ }^{2}$; however, pain is the main symptom of TMD and also the major reason for patients to seek treatment ${ }^{3}$.

Degenerative bone changes in the TMJ are significantly more frequent in the condyle than in the articular eminence, and are characterized by the presence of osteophytosis, erosions, pseudocysts, sclerosis, and flattening. These findings are considered to be radiographic signs of osteoarthritis ${ }^{4-5}$.

Clinical examination often fails to accurately detect degenerative bone changes and, therefore, radiographic examination is performed to aid in their diagnosis and treatment. The bony components of the TMJ are best detected by computed tomography ${ }^{6}$. Cone beam computed tomography (CBCT) uses less radiation than multislice $C T$ and provides a $3 D$ image of the mineralized maxillofacial tissue with minimum distortion. CBCT has been efficient in the diagnosis of several bone changes in the TMJ5.

The aim of this study was to assess degenerative bone changes in the condyle and condylar mobility with patient stratification by sex, age, and CBCT site.

\section{METHODS}

The present study was approved by the Research Ethics Committee of São Leopoldo Mandic Dental School (protocol 574.876). A convenience sample was used, including 106 CBCT images of the TMJ obtained at a private dental radiology service, located in Campina Grande, state of Paraíba, Brazil, between 2009 and 2013, from 19 male and 87 female patients. CBCT scans were obtained for the assessment of the TMJ of male and female patients older than 18 years. The scans of patients with tumor lesions and fractures in the dentomaxillofacial region, aplasias, or TMJ malformation were excluded.

The images were obtained by the same i-CAT (Imaging Sciences International, Inc, Hatfield, PA, USA) 14- bit CBCT scanner operator at $120 \mathrm{kVp}, 36 \mathrm{mAs}$. The scans were obtained with patients in maximum intercuspation and maximum mouth opening. The primary reconstruction of the raw data was limited to the TMJ region (around $1 \mathrm{~cm}$ above the mandibular fossa and $1 \mathrm{~cm}$ below the condylar head), automatically producing a series of 0.25 $\mathrm{mm}$ axial sections. By using the "TMJ" tool in the software program, on an axial view, the long axis of the condyle was sectioned, and images in the sagittal and coronal planes were then obtained. The sections were $1 \mathrm{~mm}$ thick and a 1-mm distance between them was allowed in sagittal reconstructions.

The images were assessed twice by the same radiologist, with more than 3 years' experience, at an interval of at least 30 days between the assessments of the same patient, following the method proposed by Anjos Pontual et al. ${ }^{5}$.

The images were examined by XoranCAT ${ }^{\circledR}$ software, version 3.1.62 (Xoran Technologies Inc. 2005) using a 17-inch flat-screen LCD monitor, model 5000:1 (LG, Seoul, South Korea), at a resolution of $1280 \times 1024$ pixels and maximum color quality (12 bits) in dim light.

Degenerative bone changes and condylar mobility were assessed according to the method described by Anjos Pontual (2012): 5 flattening, flat bony contour of the condyle deviating from the convex form; erosion, decreased cortical bone and adjacent subcortical bone densities; osteophyte, marginal bony outgrowth on the condyle; sclerosis, increased cortical bone density extending into the bone marrow; and pseudocyst, well-circumscribed osteolytic adjacent subcortical bone area without cortical destruction (Figure 1). Condylar mobility was estimated as follows: hypomobility, when the condyle is located posteriorly to the articular eminence; normal mobility, when the condyle is located in the articular eminence; and hypermobility, when the condyle is located anteriorly to the articular eminence, as depicted in Figure 2.

Student's $t$ test for independent samples was used to check whether age differed among individuals whose CBCT scans were included in the samples of male and female patients. The findings regarding degenerative changes in the condyle and condylar mobility were described as absolute and relative frequencies. The associations of degenerative changes in the condyle with sex and age were investigated by Fisher's exact test, $G$ test, and chi-square tests. The statistical calculations were made using SPSS 20 (SPSS INC., Chicago, IL, USA) and BioEstat 5.0 (Fundação Mamirauá, Belém, PA, Brazil), at a 5\% significance level. 


\section{RESULTS}

A total of 106 CBCT scans were assessed, 19 (17.9\%) of which belonged to male patients and 87 (82.1\%) to female individuals. Thirty-two $(30.2 \%)$ scans did not show degenerative changes in the condyle whereas 74 $(69.8 \%)$ revealed degenerative processes. The distribution of degenerative changes detected in condyles is displayed in figure 3.

Table 1 shows the absolute and relative frequencies at which alterations occurred concomitantly with different degenerative changes in the condyle and demonstrates that flattening and osteophytosis were the most prevalent associations, with a $35.8 \%$ prevalence rate.

The $\mathrm{G}$ test revealed that the prevalence of general degenerative changes was significantly associated with age (Table 2). The stratification by type of degenerative process showed that flattening was significantly more frequent among individuals older than 51 years. Even though the prevalence of erosion did not increase among those aged 41 to 60 years compared to younger individuals, this change was observed at a higher frequency in those older than 61 years. Increasing prevalence rates were found for osteophytosis in individuals older than 41 years. There was no significant association of sclerosis and pseudocyst with age.

Table 3 demonstrates that, in general, degenerative changes in the condyle were commonly bilateral (79.7\%); however, the stratification by type of degenerative process indicated higher prevalence rates both bilaterally and unilaterally. Bilateral involvement was most frequently seen in flattening and osteophytosis. Unilateral changes, on the other hand, were observed for erosion, sclerosis, and pseudocyst.

Fisiological mobility was more prevalent and commonly bilateral (Table 4).

Table 1. Absolute ( $n$ ) and relative (\%) frequencies of associations concerning degenerative changes in the condyle, detected by CBCT.

\begin{tabular}{|c|c|c|}
\hline Changes & $\mathbf{N}$ & $\%$ \\
\hline Flattening and erosion & 18 & 17.0 \\
\hline Flattening and osteophytosis & 38 & 35.8 \\
\hline Flattening and sclerosis & 9 & 8.5 \\
\hline Flattening and pseudocyst & 8 & 7.5 \\
\hline Erosion and osteophytosis & 13 & 12.3 \\
\hline Erosion and sclerosis & 6 & 5.7 \\
\hline Erosion and pseudocyst & 4 & 3.8 \\
\hline Osteophytosis and sclerosis & 12 & 11.3 \\
\hline Osteophytosis and pseudocyst & 4 & 3.8 \\
\hline Sclerosis and pseudocyst & 5 & 4.7 \\
\hline Flattening, erosion, and osteophytosis & 10 & 9.4 \\
\hline Flattening, erosion, and sclerosis & 8 & 7.5 \\
\hline Flattening, erosion, and pseudocyst & 3 & 2.8 \\
\hline Erosion, osteophytosis, and sclerosis & 5 & 4.7 \\
\hline Erosion, osteophytosis, and pseudocyst & 0 & 0.0 \\
\hline Osteophytosis, sclerosis, and pseudocyst & 3 & 2.8 \\
\hline Erosion, osteophytosis, sclerosis, and pseudocyst & 0 & 0.0 \\
\hline Flattening, erosion, osteophytosis, and sclerosis & 2 & 1.9 \\
\hline Flattening, erosion, osteophytosis, and pseudocyst & 0 & 0.0 \\
\hline Flattening, erosion, osteophytosis, sclerosis, and pseudocyst & 0 & 0.0 \\
\hline
\end{tabular}


Table 2. Absolute (n) and relative (\%) frequencies of degenerative changes in the condyle, detected by CBCT, according to age.

\begin{tabular}{|c|c|c|c|c|c|}
\hline $\begin{array}{l}\text { Degenerative } \\
\text { changes }\end{array}$ & Age (years) & Present & Absent & Total & $p$ value \\
\hline \multirow{6}{*}{ General } & $\leq 30$ & $13(48.1 \%)$ & 14 (51.9\%) & $27(25.5 \%)$ & \multirow{6}{*}{0.0014 * } \\
\hline & 31 to 40 & $13(61.9 \%)$ & $8(38.1 \%)$ & $21(19.8 \%)$ & \\
\hline & 41 to 50 & $13(65.0 \%)$ & $7(35.0 \%)$ & $20(18.9 \%)$ & \\
\hline & 51 to 60 & 20 (90.9\%) & $2(9.1 \%)$ & $22(20.7 \%)$ & \\
\hline & $\geq 61$ & $15(93.7 \%)$ & $1(6.2 \%)$ & $16(15.1 \%)$ & \\
\hline & Total & $74(69.8 \%)$ & $32(30.2 \%)$ & $106(100.0 \%)$ & \\
\hline
\end{tabular}

* $p$ values obtained from $G$ tests.

Table 3. Absolute ( $n$ ) and relative (\%) frequencies of degenerative changes in the condyle, detected by CBCT, according to CBCT site.

\begin{tabular}{|c|c|c|c|}
\hline \multirow{3}{*}{ Right side } & \multicolumn{2}{|c|}{ Left side } & \multirow{3}{*}{ Total } \\
\hline & \multicolumn{2}{|c|}{ Degenerative changes } & \\
\hline & Present & Absent & \\
\hline Present & $51(79.7 \%)$ & $13(20.3 \%)$ & $64(60.4 \%)$ \\
\hline Absent & $10(56.3 \%)$ & $32(43.7 \%)$ & $42(39.6 \%)$ \\
\hline \multicolumn{4}{|l|}{ Flattening } \\
\hline Present & $32(62.7 \%)$ & $19(37.3 \%)$ & $51(48.1 \%)$ \\
\hline Absent & $11(20.0 \%)$ & $44(80.0 \%)$ & $55(51.9 \%)$ \\
\hline Total & $43(40.6 \%)$ & $63(59.4 \%)$ & $106(100.0 \%)$ \\
\hline Absent & $13(13.7 \%)$ & $82(86.3 \%)$ & $95(89.6 \%)$ \\
\hline Total & $16(15.1 \%)$ & $90(84.9 \%)$ & $106(100.0 \%)$ \\
\hline \multicolumn{4}{|c|}{ Osteophytosis } \\
\hline Present & $28(68.3 \%)$ & $13(31.7 \%)$ & $41(38.7 \%)$ \\
\hline Absent & $6(9.2 \%)$ & $59(90.8 \%)$ & $65(61.3 \%)$ \\
\hline Total & $34(32.1 \%)$ & $72(67.9 \%)$ & $106(100.0 \%)$ \\
\hline Present & $0(0.0 \%)$ & $4(100.0 \%)$ & $4(3.8 \%)$ \\
\hline Absent & $7(6.9 \%)$ & $95(93.1 \%)$ & $102(96.2 \%)$ \\
\hline Total & $7(6.6 \%)$ & $99(93.4 \%)$ & $106(100.0 \%)$ \\
\hline
\end{tabular}


Table 4. Absolute ( $n$ ) and relative (\%) frequencies of the type of condylar mobility, detected by $C B C T$, according to the site.

\begin{tabular}{|c|c|c|c|}
\hline \multirow{3}{*}{ Right side } & \multicolumn{2}{|c|}{ Left side } & \multirow{3}{*}{ Total } \\
\hline & \multicolumn{2}{|c|}{ Degenerative changes } & \\
\hline & Present & Absent & \\
\hline Present & $38(71.7 \%)$ & $15(28.3 \%)$ & $53(50.0 \%)$ \\
\hline Absent & $10(18.9 \%)$ & $43(81.1 \%)$ & $53(50.0 \%)$ \\
\hline \multicolumn{4}{|c|}{ Hypomobility } \\
\hline Present & $22(78.6 \%)$ & $6(21.4 \%)$ & $28(26.4 \%)$ \\
\hline Absent & $8(10.3 \%)$ & $70(89.7 \%)$ & $78(73.6 \%)$ \\
\hline Total & $30(28.3 \%)$ & $76(71.7 \%)$ & $106(100.0 \%)$ \\
\hline Absent & $10(12.0 \%)$ & $73(88.0 \%)$ & $83(78.3 \%)$ \\
\hline Total & $30(28.3 \%)$ & $76(71.7 \%)$ & $106(100.0 \%)$ \\
\hline
\end{tabular}

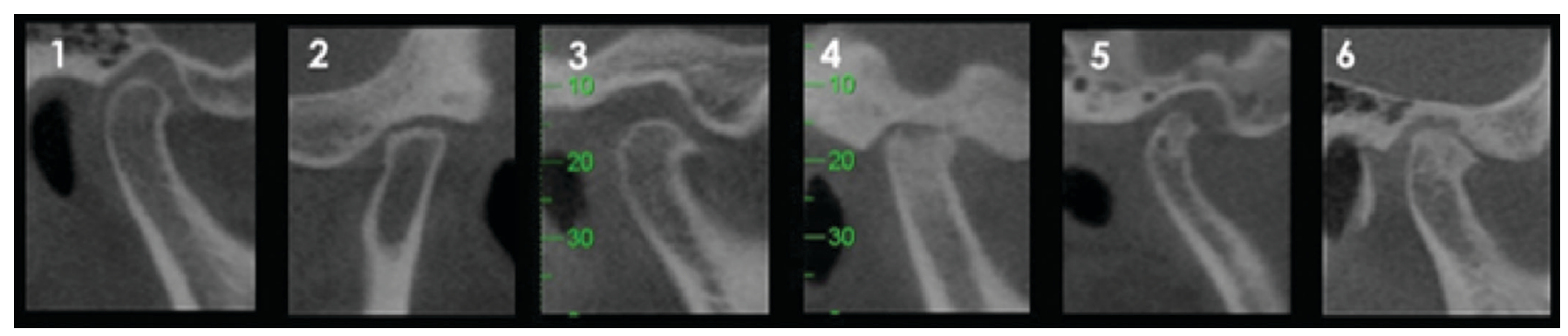

Figure 1. Sagittal sections of the TMJ in maximum intercuspation with degenerative bone changes in the condyle.

Legend: (1) No changes, (2) Flattening, (3) Osteophytosis, (4) Erosion, (5) Pseudocyst, (6) Sclerosis and osteophytosis.

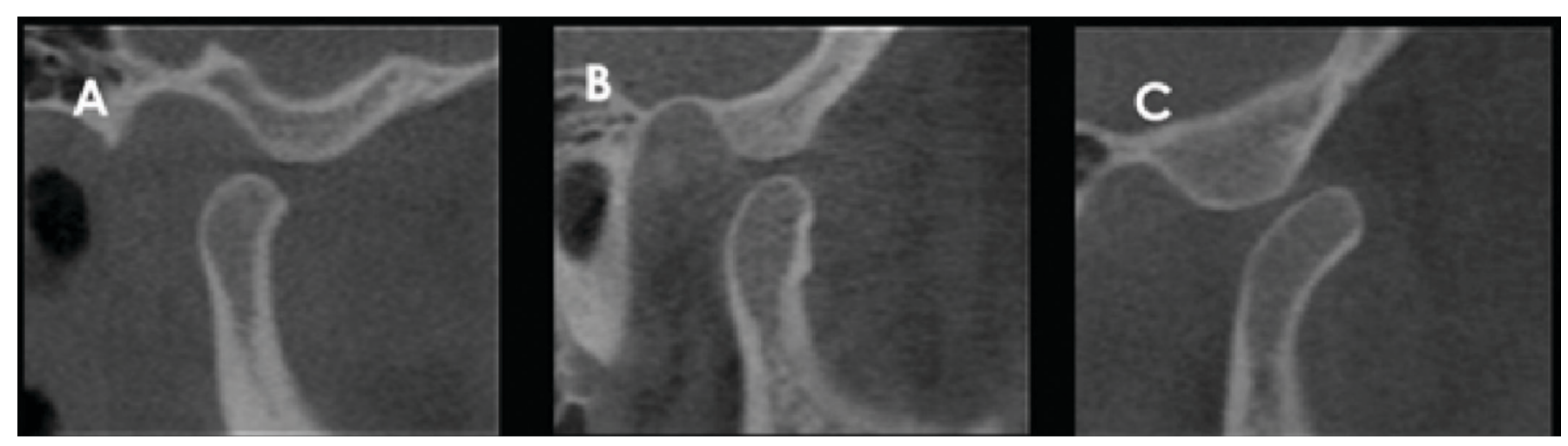

Figure 2. Sagittal sections of right TMJ in maximum mouth opening with condylar mobility. Legend: A) Hypomobility, B) Normal mobility, C) Hypermobility. 


\section{$\square$ With $\square$ Without}

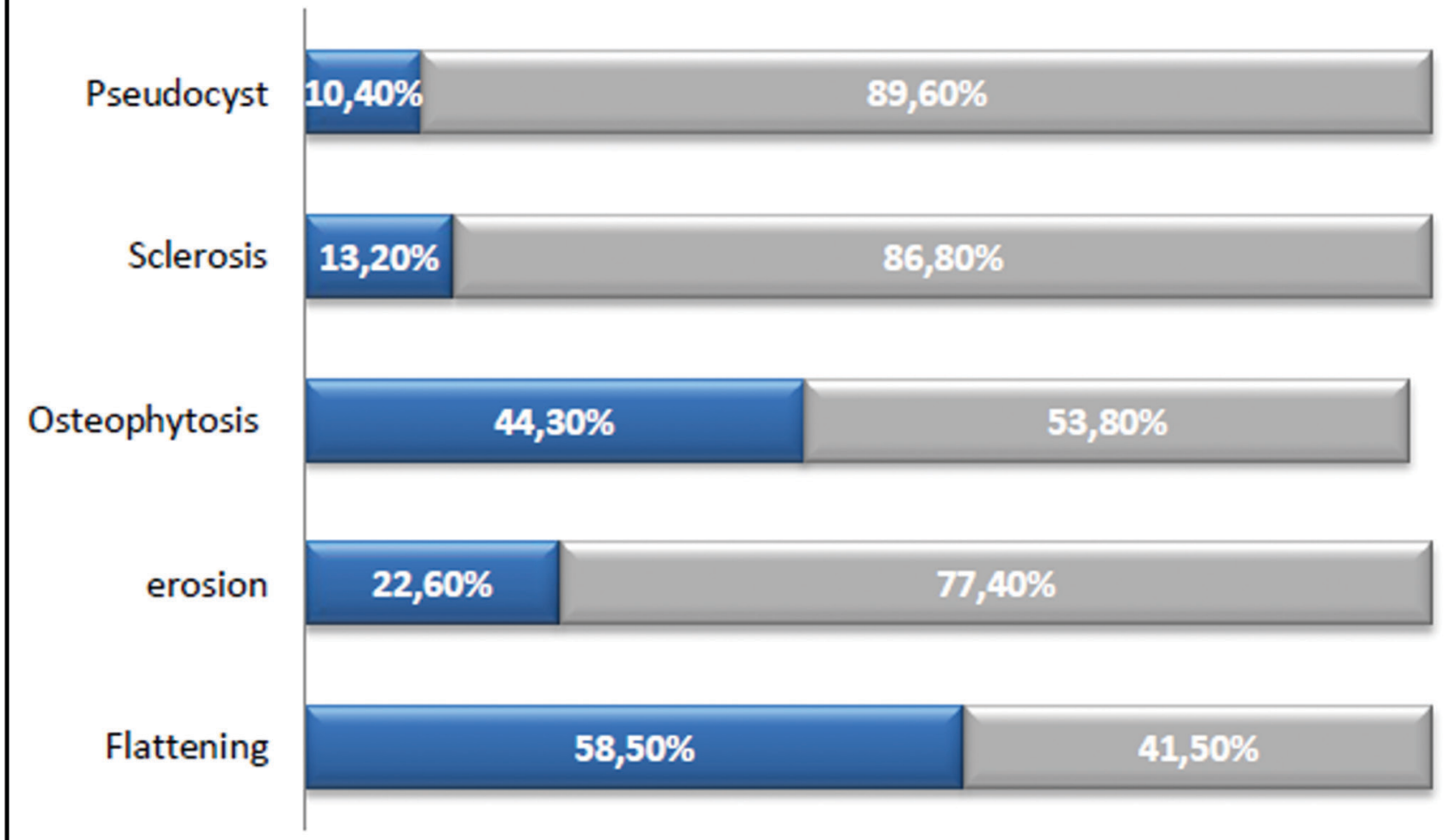

Figure 3. Prevalence of degenerative changes in condyle.

\section{DISCUSSION}

CBCT allows the visualization of TMJ components without overlapped and distorted images. Compared to panoramic radiography and (linear/spiral) tomography of the TMJ, CBCT provides a significantly more reliable diagnosis. Therefore, it accurately detects bone changes, such as remodeling, erosion, flattening, osteophytosis, subchondral sclerosis, and ankylosis, in the condyle, in the temporal fossa, and in the articular eminence ${ }^{7}$.

The use of CBCT in this study detected a $69.8 \%$ prevalence of bone changes in the TMJ, which is consistent with other studies ${ }^{5,8}$. The high prevalence may be attributed to the fact that the sample of patients referred to the dental radiology service had been previously examined by a dentist, with clinical symptoms or signs and/or abnormal TMJ images on previous radiographs; and because of that, CBCT was requested.

According to literature reviews, degenerative bone changes in the TMJ are more frequent among women than among men. In this study, $82.1 \%$ were female and
$17.9 \%$ were male, as also reported in other studies s-5,8-10. $^{2}$. Liu \& Steinkeler ${ }^{2}$ observed that TMD symptoms are more prevalent in women than in men, and that women tend to develop TMD, especially after menopause. The rationale behind the prevalence of TMD has not been elucidated yet, but the influence of hormones, mainly estrogen, has been suggested. Dibai-Filho et al. ${ }^{11}$ declared that women are mostly affected by TMD owing to anatomic, biological, and hormonal factors.

According to Cevidanes et al. ${ }^{12}$ osteoarthritis is age-related, that is, both the progression and severity of degenerative bone changes in the condyle and in the mandibular fossa increase with age. The results of the present study evidenced a higher rate of changes as age advanced, showing that individuals older than 51 years were the most affected ones, as corroborated by other studies ${ }^{5,8}$.

The most frequent degenerative bone changes in the condyle were flattening (58.5\%) and osteophytosis $(44.3 \%)$, followed by erosion $(22.6 \%)$, sclerosis $(13.2 \%)$, and pseudocyst $(10.4 \%)$, in line with Anjos Pontual et 
al. ${ }^{5}$ who also observed flattening and osteophytosis as the most predominant degenerative bone changes. Conversely, Oliveira et al. ${ }^{9}$ found a higher prevalence of flattening and bony sclerosis, followed by osteophytosis. Cevidanes et al. ${ }^{12}$ detected $60 \%$ of flattening and $40 \%$ of erosion and osteophytosis. By using magnetic resonance, Oliveira et al. ${ }^{4}$ demonstrated that osteophytosis was the most prevalent change, followed by sclerosis and erosion, not including flattening.

Alexiou et al. ${ }^{8}$ described erosion, flattening, and osteophytosis as the most frequent degenerative changes in the condyle, and sclerosis as the least frequent change; however, there was statistically significant difference in the mean age of patients with sclerosis, which was detected among older patients, unlike the findings of the present study, in which sclerosis was not significantly associated with age.

The high prevalence of flattening observed in this sample may be explained by the possibility that such finding could be an adaptive change, in addition to a degenerative change resulting from an overload on the TMJ. However, it is often difficult to radiographically distinguish advanced remodeling from degenerative joint disease. It was observed that flattening, pneumatized articular eminence, and the decrease in condylar size were likely to occur even after the signs and symptoms of TMD have resolved or been mitigated $^{13}$.

The present study showed concomitant and different degenerative condylar changes and revealed that the most prevalent alterations were associated with flattening and osteophytosis (prevalence of $35.8 \%$ ), followed by flattening and erosion (prevalence of $17.0 \%$ ), whereas erosion in association with osteophytosis had a prevalence of $12.3 \%$ and osteophytosis associated with sclerosis had a rate of $11.3 \%$. A similar result was described by Anjos Pontual et al. 5 who found the association between osteophytosis and flattening to be the most prevalent. Nevertheless, Oliveira et al.4 concluded that erosion + osteophytosis was the most frequent association, but one should recall that those authors did not include flattening in their study.

TMJ is the only bilateral joint that works with just one functional unit. Given that jaw movements are coordinated by both joints simultaneously, that could explain the high prevalence of bilateral changes, as observed in the present study.
Pasinato et al. ${ }^{14}$ asserted that joint hypermobility is related to the development of TMD signs and symptoms. In this study, normal mobility was more prevalent, followed by hypomobility and hypermobility. Notwithstanding, in this study, there was no correlation between condylar mobility and the presence of degenerative bone changes, as also reported by Anjos Pontual et al. ${ }^{5}$ On the other hand, Oliveira et al. ${ }^{9}$ observed a predominance of hypermobility in $80.75 \%$ of patients with degenerative bone changes.

Osteoarthritis is a chronic disease, and as any chronic process, it has destructive and reparative characteristics, both of which often occur simultaneously. ${ }^{15}$ The bone changes assessed herein may be related to osteoarthritis, which is a local inflammatory condition that occurs when the balance between bone destruction and repair is compromised, resulting in disc displacement and degeneration of bone structures, causing clinical signs and symptoms such as pain and joint sounds; ${ }^{12}$ however, only the images of these changes were evaluated. Thus, future research, combining images of degenerative bone changes and clinical history of the patients, is necessary to improve the diagnosis of osteoarthritis.

\section{CONCLUSION}

Considering the results obtained in the present study, the degenerative bone changes occurred more frequently among women and in bilateral location and there was an increasing of alterations according the age. It was not found correlation among condylar mobility and the presence of degenerative bone alterations of the TMJ.

\section{Collaborators}

MQ ALMEIDA-AZEVEDO was the main investigator, participated in the data collection and writing the manuscript. RQ ALMEIDA-BARROS and LFA DONATO also participated in the data collection and data interpretation. LRC MANHÃES-JÚNIOR contributed to the data analysis and reviewing the manuscript. MN YOUSSEF contributed to the data interpretation and reviewing the manuscript. FK PANZARELLA prepared the study design, supervised all stages of research from conception and writing and final revision of the text. All authors reviewed the text and approved its final version. 


\section{REFERENCES}

1. Krishnamoorthy B, Mamatha NS, Vinod Kumar AR. TMJ imaging by CBCT: current scenario. Ann of Maxillofac Surg. 2013;1(3):80-3. doi: 10.4103/2231-0746.110069.

2. Liu F, Steinkeler A. Epidemiology, diagnosis, and treatment of temporomandibular disorders. Dent Clin North Am. 2013;57(3):465-79. doi: 10.1016/j.cden.2013.04.006

3. Tjakkes GH, Reinders JJ, Tenvergert EM, Stegenga B. TMD pain: the effect on health related quality of life and the influence of pain duration. Health Qual Life Outcomes. 2010;8:46. doi: 10.1186/1477-7525-8-46.

4. Oliveira JX, Rosa JA, Dutra MEP, Santos KCP, Gil C. Assessing joint effusion and bone changes of the head of the mandible in MR images of symptomatic patients. Braz Oral Res. 2013;27(1):37-41.

5. Anjos Pontual ML, Freire JSL, Barbosa JMN, Frazão MAG, Anjos Pontual A. Evaluation of bone changes in the temporomandibular joint using cone beam CT. Dentomaxillofac Radiol. 2012;41(1):24-9. doi: 10.1259/ dmfr/17815139

6. Yadav S, Palo L, Mahdian M, Upadhyay M, Tadinada A. Diagnostic accuracy of 2 cone-beam computed tomography protocols for detecting arthritic changes in temporomandibular joints. Am J Orthod Dentofacial Orthop. 2015;147(3):339-44. doi: 10.1016/j.ajodo.2014.11.017

7. Dula K, Bornstein MM, Buser D, Dagassan-Berndt D, Ettlin DA, Filippi $A$, et al. SADMFR guidelines for the use of conebeam computed tomography/ digital volume tomography. Swiss Dent J. 2014;124(11):1169-83.

8. Alexiou KE, Stamatakis HC, Tsiklakis K. Evaluation of the severity of temporomandibular jointosteoarthritic changes related to age using cone beam computed tomography. Dentomaxillofac Radiol. 2009;38(3):141-7. doi: 10.1259/ $\mathrm{dmfr} / 59263880$
9. Oliveira LCG, Andrade RP, Ponzi EAC. Diagnóstico das patologias encontradas nas tomografias corrigidas para articulação têmporo-mandibular. Int J Dent. 2008;7(1):2832.

10. Nah KS. Condylar bony changes in patients with temporomandibular disorders: a CBCT study. Imaging Sci Dent. 2012;42(4):249-53. doi: 10.5624/isd.2012.42.4.249

11. Dibai-Filho AV, Costa ACS, Packer AC, Castro EM, Rodrigues-Bigaton D. Women with more severe degrees of temporomandibular disorder exhibit an increase in temperature over the temporomandibular joint. Saudi Dent J. 2015;27(1):44-9. doi: 10.1016/j.sdentj.2014.10.002.

12. Cevidanes LHS, Hajati A-K, Paniagua B, Lim PF, Walker DG, Palconet $\mathrm{G}$, et al. Quantification of Condylar Resorption in TMJ Osteoarthritis. Oral Surg Oral Med Oral Pathol Oral Radiol Endod. 2010;110(1):110-7. doi: 10.1016/j. tripleo.2010.01.008

13. Sano T, Otonari-Yamamoto M, Otonari T, Yajima A. Osseous abnormalities related to the temporomandibular joint. Semin Ultrasound CT MR. 2007;28(3):213-221. doi:10.1053/j. sult.2007.02.006

14. Pasinato F, Souza JA, Corrêa EC, Silva AM. Temporomandibular disorder and generalized joint hypermobility: application of diagnostic criteria. Braz J Otorhinolaryngol. 2011;77(4):41825. doi: 10.1590/S1808-86942011000400003

15. Ferrazzo KL, Osório LB, Ferrazzo VA. CT Images of a Severe TMJ Osteoarthritis and Differential Diagnosis with Other Joint Disorders. Case Rep Dent. 2013;2013:242685. doi: 10.1155/2013/242685. 


\section{Errata}

No artigo Degenerative bone changes in TMJ assessed by cone beam computed tomography, com número de DOI: http://dx.doi.org/10.1590/1981-863720160002000073191, publicado no periódico RGO, Revista Gaúcha de Odontologia, 64(2):171-178, na <página 171>

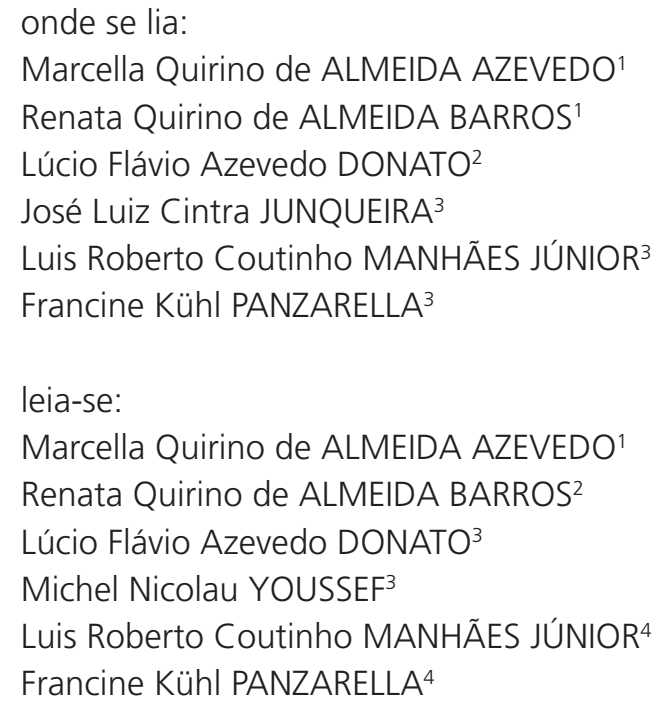

Onde se lia:

1 Centro Universitário de João Pessoa, Departamento de Radiologia Oral. Rod. BR 30, km 22, s/n., 58053-000, Água Fria, João Pessoa, PB, Brasil. Correspondência para / Correspondence to: MQA AZEVEDO. E-mail: <marcella_q_almeida@hotmail.com>.

${ }^{2}$ Faculdade Associação Caruaruense de Ensino Superior, Departamento de Clínica Integrada. Caruaru, PE, Brasil.

3 Faculdade São Leopoldo Mandic, Curso de Odontologia, Programa de Pós-Graduação em Odontologia. Campinas, SP, Brasil.

leia-se:

1 Faculdade Maurício de Nassau, Departamento de Odontologia. Br 232 com a Br 104, KM 68, 1215, Caruaru, PE, Brasil. Correspondência para / Correspondence to: MQA AZEVEDO. E-mail: <marcella_q_almeida@hotmail.com>.

${ }^{2}$ Centro Universitário de João Pessoa, Departamento de Odontologia. João Pessoa, PB, Brasil.

${ }^{3}$ Universidade Cruzeiro do Sul, Departamento de Odontologia. São Paulo, SP, Brasil.

${ }^{4}$ Faculdade São Leopoldo Mandic, Curso de Odontologia, Programa de Pós-Graduação em Odontologia. Campinas, SP, Brasil. 